Linha D'Água (Online), São Paulo, v. 30, n. 1, p. 35-68, jun. 2017

\title{
POLARIZAÇÃO E CONSTRUÇÃO DA FORÇA DISCURSIVA EM MANIFESTOS POLÍTICOS: O CASO DAS PRESIDENCIAIS PORTUGUESAS DE 2016
}

\author{
POLARIZATION AND THE CONSTRUCTION OF THE DISCURSIVE \\ FORCE IN THE POLITICAL MANIFESTOS: THE CASE OF 2016 \\ PORTUGUESE PRESIDENTIAL ELECTIONS
}

\author{
Maria Alexandra Araujo Guedes Pinto*, Ana Catarina Fonseca Almeida e

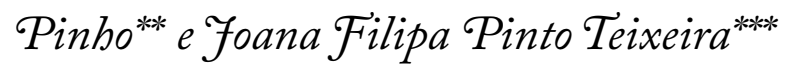 \\ Universidade do Porto, Porto, Portugal
}

\begin{abstract}
Resumo: 0 presente estudo analisa o manifesto polfíico apresentado publicamente por um dos dez candidatos às eleiçōes presidenciais portuguesas de janeiro de 2016.0 objefivo do estudo é, através do quadro de análise proposto por Adam (2001) para a descrição dos gêneros textuais em oito componentes (semûntica; composicional; enunciativa; pragmática; estilistico-fraseológica; metatextual; peritextual e material), proceder a uma análise completa e integrada do texto, que torne visíveis os princípios centrais da sua organização argumentativa enunciativa e pragmática e, logo, os princípios da sua força discursiva. Ao mesmo tempo, a análise contribuirá para a descriç̃õo deste gênero de texto, pertencente ao tipo de discurso políico, situando o texto numa zona prototííca do gênero.
\end{abstract}

Palavras-chave: Manifesto político; Gênero de texto; Força discursiva; Organização argumentativa, enunciativa e pragmática.

\begin{abstract}
The present study analyzes the political manifesto publicly presented by one of the ten candidates to the Porruguese presidential elections of January 2016. The objective of the study is, through the framework of analysis proposed by Adam (2001) for the description of the textual genres in eight components (semantic, compositional, enunciative, pragmatic, stylistic-phraseological, metatextual, peritextual and material), to carry out a complete and integrated analysis of the text that makes visible the main principles of its argumentative, enunciative and pragmatic organization and hence the principles of its discussive force. At the same time, the analysis will contribute to the description of this text genre belonging to the political discourse type, placing the text in a prototypical area of the genre.
\end{abstract}

Keywords: Political manifesto; Text genre; Discusiviv Force; Argumentative, Enunciative and Pragmatic Organization.

\footnotetext{
* Professora auxiliar da Faculdade de Letras da Universidade do Porto - FLUP, Porto, Portugal; mapinto@letras.up.pt

** Doutoranda da Faculdade de Letras da Universidade do Porto - FLUP, Porto, Portugal; up201601367@letras.up.pt.pt

***Doutoranda da Faculdade de Letras da Universidade do Porto - FLUP, Porto, Portugal; joanajteixeira@outlook.com
} 
Linha D'Água (Online), São Paulo, v. 30, n. 1, p. 35-68, jun. 2017

\section{Introdução}

No nosso trabalho concentrar-nos-emos na análise do manifesto presidencial do candidato Edgar Silva às eleições presidenciais portuguesas de 2016. O objetivo da nossa análise é isolar as estratégias discursivas que serviram de suporte ao objetivo pragmático do autor de conquistar o maior número de votos nas referidas eleições.

O manifesto presidencial é um gênero de texto que se insere dentro do tipo de discurso político, apresentando uma estrutura maioritariamente expositiva e argumentativa. Tem como objetivo expor as propostas do locutor, comprometendo-o com estas, e apelar à adesão do alocutário, levando-o a realizar a ação pretendida, que é, neste caso específico, confiar o voto ao candidato Edgar Silva. Para concretizar a sua especificidade pragmática, o manifesto presidencial exibe marcas linguísticas regulares, que nos propomos identificar neste artigo.

Este manifesto, identificado pelo candidato como "Declaração de Candidatura" ${ }^{1}$, foi proferido pelo mesmo a 15 de outubro de 2015, na sala Europa do Hotel Altis em Lisboa, perante uma audiência de militantes e simpatizantes do Partido Comunista Português (PCP). O manifesto viria posteriormente a ser colocado na página web da candidatura e na própria página do Partido. Trata-se do manifesto mais extenso de todos os manifestos apresentados pelos restantes candidatos nestas eleições, tendo um total de 11 páginas, 3929 palavras, distribuídas por sete secções. O mote da campanha de Edgar Silva foi: "Afirmar os valores de Abril", num claro alinhamento, mantido ao longo do período eleitoral, com os valores do Partido Comunista Português.

Analisaremos o manifesto em causa tomando como referência o quadro de análise dos gêneros textuais proposto por Jean Michel Adam (2001), que prevê a caracterização do gênero em oito componentes, a saber: a componente semântica; a componente enunciativa; a componente pragmática; a componente composicional; a componente estilístico-fraseológica; a componente metatextual, a componente

1 O texto surge com um título ligeiramente diferente em cada uma das duas plataformas digitais em que esteve disponível. No site do Partido Comunista Português surge identificado com um título mais extenso: "Declaração de candidatura de Edgar Silva à Presidência da República"; já no site da própria candidatura, surge com um título mais abreviado: "Declaração de Candidatura". 
Linha D'Água (Online), São Paulo, v. 30, n. 1, p. 35-68, jun. 2017

peritextual e a componente material ${ }^{2}$. Este quadro, ao prever o tratamento integrado das oito componentes mencionadas, permite-nos fazer um mapeamento linguístico-discursivo completo do texto e do gênero em que o mesmo se insere.

O nosso objetivo é, não só contribuir para a delimitação deste gênero de texto, mas, também, particularizar certos mecanismos da construção da sua força discursiva.

\section{0 gênero textual}

Retomando, muito sumariamente, o que Jean Michel Adam entende por cada um dos parâmetros acima designados, relembramos que a componente semântica procura identificar os temas, as representações discursivas presentes no texto, se as mesmas são de caráter ficcional ou não ficcional, por exemplo; a componente composicional pretende estabelecer a estrutura do texto, identificar as sequências textuais dominantes e o plano de texto subjacente; a componente enunciativa permite caracterizar a ancoragem situacional do texto, com a identificação dos interlocutores, da área sóciodiscursiva em que se inserem, do estatuto profissional por eles assumido no momento da produção textual e da construção da sua responsabilidade enunciativa; a componente estilístico-fraseológica diz respeito à textura microlinguística do texto (frástica e transfrástica), determinando aspetos como, por exemplo, as seleções lexicais ou as construções sintáticas, entre outros; a componente pragmática concentra-se na identificação dos objetivos ilocutórios do texto e na caracterização da sua orientação argumentativa; a componente metatextual refere-se às formas como o texto se autoidentifica, exibindo ou não "rótulos" de pertença ao gênero; a componente peritextual assinala as fronteiras do texto, fronteiras que adquirem diversas formas, consoante o gênero em questão e, finalmente, a componente material diz respeito ao suporte material do texto, a sua extensão, o meio de circulação do mesmo e, no caso dos textos escritos, questões de natureza tipográfica.

2 Por falta de espaço, não incluiremos um tratamento explícito das componentes material e peritextual do manifesto em análise neste estudo. 
Linha D'Água (Online), São Paulo, v. 30, n. 1, p. 35-68, jun. 2017

Faremos, como já referido, uma caracterização do manifesto a estes diferentes níveis, com a intenção de extrair conclusões relevantes sobre a organização discursiva do texto e do gênero que ele representa.

\subsection{A componente metatextual no manifesto político}

O texto intitulado "Declaração de Candidatura" explicita, logo no título, várias informações relevantes para a sua caracterização de acordo com as componentes propostas por Jean Michel Adam. Antes de mais, inclui uma referência metatextual ao gênero em que se insere, através do rótulo "Declaração". Este rótulo é depois retomado no texto 14 vezes de forma abreviada, através da palavra "candidatura", que se faz anteceder normalmente dos determinantes possessivos e demonstrativos "a minha"; "a nossa", "esta". Existe, assim, uma inscrição explícita no gênero "manifesto político", que não se dá através do rótulo "manifesto", mas através da sua variante "declaração". É de notar, aliás, que os candidatos à Presidência da República das eleições presidenciais portuguesas de 2016 nomeiam de formas variadas os seus textos de apresentação pública de candidatura, corroborando, como defendem Adam e Heidmann (2007, p. 8), que os textos concretos atualizam as características do gênero de forma diferenciada, dado que os gêneros "sont des categorisations dynamique en variation". Marcelo Rebelo de Sousa, por exemplo, não identifica o seu texto com qualquer rótulo; António Sampaio da Nóvoa intitula-o como "Carta de Princípios", entre outros exemplos possíveis.

Não obstante esta dispersão, que se soma à dispersão das características dos textos em si, todos os textos foram pronunciados em circunstâncias contextuais idênticas, para cumprir um objetivo performativo comum, que foi o de formalizar, perante os eleitores, a candidatura de um dado político às eleições presidenciais.

\subsection{A componente pragmática: atos ilocutórios dominantes}

No título deste manifesto também está patente uma informação de natureza pragmática relevante que é o facto de este se apresentar como uma declaração. As declarações são um dos atos ilocutórios previstos por Searle (1976), que se definem 
por trazerem, de forma imediata, um novo estado de coisas à existência. Neste caso, um dado cidadão, através da produção de um dado enunciado público, alterou o seu estatuto de cidadão comum para o de candidato presidencial.

Embora se assuma como um texto performativo, institucional e este seja o seu macro-objetivo ilocutório ${ }^{3}$, no interior da declaração é possível encontrar vários micro-atos ilocutórios e estabelecer até uma hierarquia de atos ilocutórios dominantes. Num primeiro momento do texto em que, do ponto de vista semântico, o candidato procede a um diagnóstico do estado do país, predominam os atos ilocutórios expressivos de crítica e os atos assertivos avaliativos, com valor derivado de crítica; num segundo momento do texto, em que o candidato apresenta os fundamentos da sua candidatura e o seu programa de ação, predominam os atos compromissivos e surgem também atos diretivos de apelo. Podemos atestar, por estudos anteriormente já efetuados sobre tokens do mesmo gênero textual (PINTO, 2013) que esta divisão semântico-pragmática é relativamente prototípica nos manifestos políticos.

São exemplos de atos expressivos de crítica e de atos assertivos avaliativos, enunciados como:

(1) Este é um tempo em que, em Portugal, depois de décadas de governação em confronto com os valores de Abril, se aprofundam as injustiças sociais e a exploração (...).

(2) Multiplica-se a degradação social. Acentuam-se as chagas ambientais e agravamse os problemas dos trabalhadores e alastra a pobreza, tudo na decorrência directa do domínio absoluto dos grandes grupos económicos.

(3) (...) degrada-se a injusta ordem internacional assente na despótica lógica dos mercados que, por cima dos Povos e dos Estados, se vai apropriando de todas as decisões e escolhas, multiplicando focos de tensão e de guerra, espalhando os terriveis flagelos das migraçôes forçadas e dos refugiados, do desemprego, da fome e da miséria, que mergulham grande parte da Humanidade em indizíveis carências e intoleráveis sofrimentos.

3 Este macro-ato é anunciado no título do manifesto e repetido na primeira linha do discurso, onde se pode ler: "Apresento hoje a declaração da minha candidatura a Presidente da República." 
Linha D'Água (Online), São Paulo, v. 30, n. 1, p. 35-68, jun. 2017

(4) Não podemos ser cúmplices do ataque ao Serviço Nacional de Saúde e à Escola Pública.

(5) Não podemos pactuar com o corte nas prestações sociais, com o roubo aos rendimentos, com a brutal injustiça fiscal, com o desemprego, a precariedade, a violação de direitos, enquanto se refina a proteção e apoio ao grande capital, que não pára de aumentar os seus colossais lucros. ${ }^{4}$

São exemplos de atos compromissivos de promessa, enunciados como:

(6) Comprometo-me, pois, a tudo fazer quanto à salvaguarda da «Constituição Laboral», naquele que é o capítulo sobre os direitos, liberdades e garantias dos trabalhadores.

(7) Comprometo-me com a causa da libertação das amarras da pobreza, encarando-a como dever do Presidente da República (...).

(8) Com esta candidatura assumo plenamente o exercício de todos os direitos (...) e afirmo a total disponibilidade para exercer as funções que o Povo Português entenda atribuir-me nesta eleição.

(9) Como candidato ou como Presidente da República defenderei, intransigentemente, os ideais libertadores de Abril (...).

(10) (...) defenderei um outro rumo para Portugal que comporte a valorização do trabalho e dos trabalhadores (...).

E, finalmente, são exemplo de enunciados diretivos, passagens como as seguintes:

(11) Urge encetar caminhos novos.

(12) É preciso defender a Autonomia (...).

(13) É preciso inverter o processo de ataque e desfiguração do Poder Local Democrático (...).

4 Como verificamos, nos exemplos (4) e (5) o ato de crítica acontece enquadrado num ato diretivo de recomendação explicitado pelo modal deôntico "Não podemos $x$ ". A conjugação destes dois atos ilocutórios num só enunciado gera um complexo ilocutório forte. 
Linha D'Água (Online), São Paulo, v. 30, n. 1, p. 35-68, jun. 2017

(14) Não podemos ficar indiferentes ao acentuar do processo de regressão social, de acumulação e polarização da riqueza.

(15) O Presidente da República não pode deixar, no âmbito das suas competências e responsabilidades próprias, de defender a mobilização do Povo Português na busca de um outro rumo de desenvolvimento (...).

\subsection{A componente composicional: a sequência argumentativa}

Decorrente do que dissemos acima, podemos afirmar que o manifesto de Edgar Silva se divide, do ponto de vista composicional, em duas grandes partes de orientação semântico-pragmática bastante diferenciada: a parte em que o candidato efetua uma reflexão sobre a situação atual do país, tecendo duras críticas à atual classe política dirigente por não ser capaz de dar resposta aos problemas referenciados e a parte em que apresenta o seu projeto para o país.

$\mathrm{Na}$ primeira parte incluem-se as primeiras quatro secções do discurso do candidato que se intitulam, respetivamente:

I [Apresento hoje a declaração da minha candidatura a Presidente da República $]^{5}$

II Quem acolhe o grito dos pobres?

III Quem atende ao clamor dos trabalhadores?

IV Quem, nesta República, ouve o clamor da terra?

Como constatamos, os títulos das secções II, III e IV são formulados através de perguntas retóricas, o que é muito relevante quanto à construção argumentativa do texto, facto que desenvolveremos adiante, no momento em que abordarmos a questão das sequências textuais dominantes.

$\mathrm{Na}$ segunda parte, incluem-se as restantes três secções do texto, que recebem a seguinte intitulação por parte do autor:

5 Reconstituímos o título desta primeira parte que, curiosamente, surge identificado numa das páginas web onde o discurso ficou disponível (o site do Partido Comunista Português) e não identificado na outra página, a saber, a página oficial da candidatura de Edgar Silva. 
V O papel do Presidente da República

VI Linhas de atuação fundamentais

VII [Conclusão]

Embora estas sejam partes em que o candidato aproveita para fazer algumas críticas à presidência da república da época, são sobretudo etapas em que ele apresenta a sua visão relativamente ao cargo máximo da nação e o seu programa de ação.

$\mathrm{Na}$ componente composicional, de acordo com J. M. Adam, torna-se também relevante descrever as sequências textuais predominantes no texto. Neste manifesto encontramos o predomínio de sequências textuais argumentativas em concomitância com sequências textuais expositivas e instrucionais / diretivas.

Retomando as palavras de Adam:

Apesar dessa heterogeneidade frequente, a caracterização global de um texto resulta de um efeito dominante: o todo textual é, na sua globalidade e sob a forma de resumo, caracterizável como predominantemente narrativo, argumentativo, explicativo, descritivo ou dialogal. (ADAM, 2011, p. 275).

Assim, é possível dizer que a sequência argumentativa domina o manifesto presidencial em análise, tomando em consideração o conceito de "dominante" de Adam (2011, p. 272), que se infere pela sequência encaixante; pelo predomínio de sequências do mesmo tipo e pela sequência através da qual o texto pode ser resumido. Esta sequência dominante integra depois subsequências encaixadas, de natureza maioritariamente expositiva e instrucional / diretiva.

A sequência argumentativa pode ser exemplificada através de todos aqueles segmentos do texto organizados sob a forma de paralelismo estrutural, já que estes evidenciam uma estrutura retórica forte. Há quatro grandes momentos de paralelismo estrutural no texto: quando o candidato diagnostica o ponto de situação do país, em que as estruturas recursivas são: "Há x" e "Este é um tempo em que x"; quando tenta evidenciar a necessidade de mudança, referindo, simultaneamente, o estado de coisas que é urgente mudar, em que repete estruturas tais como: "Este é um rumo/um caminho inaceitável", "Não podemos x" e a interrogação retórica 
Linha D'Água (Online), São Paulo, v. 30, n. 1, p. 35-68, jun. 2017

"Quem x?"; quando apresenta aspetos do seu programa, usando estruturas como: "Como Presidente da República, x", "Esta é uma candidatura x" e "É preciso defender/inverter x", "Comprometo-me a x / Aqui me comprometo a x"; e, finalmente, como forma de fecho do discurso, nas saudações finais: "Viva $x$ ".

Dada a saliência das estruturas paralelísticas no texto, que organizam praticamente todas as secções do mesmo, limitar-nos-emos a exemplificar algumas destas ocorrências:

(16) Quem, nesta República, tem em conta os direitos fundamentais dos mais desfavorecidos? Quem escuta o clamor dos excluídos deste mundo? Quem responde por milhões de pessoas indefesas face aos "interesses do mercado divinizado, transformado em regra absoluta”? Quem responde por tanta gente sacrificada pela desenfreada especulação financeira? Quem acolhe o grito das vítimas dos poderes económicos e dos seus interesses predominantes que arrasam tanta vida e a fonte da vida? Quem se compromete com a justa causa daqueles que estão a ser sufocados pelo domínio absoluto do lucro?

(17) Não podemos ficar indiferentes ao acentuar do processo de regressão social, de acumulação e polarização da riqueza. Não podemos aceitar a continuada alienação do património público e a destruição da nossa estrutura produtiva. Não podemos tolerar que se dissimulem os níveis dramáticos de desemprego, das gritantes desigualdades sociais, de negação a milhões de Portugueses (...).

(18) Esta candidatura que assumo exprime essa exigência de uma profunda ruptura e de viragem em relação às orientações políticas que tanta desordem e tanta regressão impuseram ao nosso País (...).

(19) Esta candidatura está comprometida com os valores de Abril, para impulsionar o caminho do desenvolvimento, da Justiça e do progresso social, da soberania e independência nacionais.

(20) Esta candidatura está vinculada, inabalavelmente, ao projecto de Abril, inscrito na Constituição da República Portuguesa, que comemora, em breve, o seu $40 .^{\circ}$ aniversário, que incorpora uma base programática e constitui uma plataforma política capaz de unir os Portugueses no abrir das novas avenidas de esperança e de futuro para Portugal. 
Linha D'Água (Online), São Paulo, v. 30, n. 1, p. 35-68, jun. 2017

A sequência argumentativa é também explicitamente apresentada pelo autor nas passagens em que este declara textualmente "Eu defendo x", tal como se lê no excerto abaixo:

(21) Defendo que um outro Portugal é possível. Com uma economia mista que defenda os recursos e a produção nacional, o emprego, que promova a ciência e a tecnologia, que desenvolva e modernize as capacidades produtivas nacionais, que desenvolva a economia do mar e apoie os pescadores, apoie e incentive as micro, pequenas e médias empresas. Com uma perspectiva de desenvolvimento que não abandone o interior, que apoie os pequenos e médios agricultores, nem promova uma desequilibrada concentração de populações, equipamentos, actividades e serviços em áreas desordenadas e entregues à especulação imobiliária. Com um modelo de desenvolvimento que não hipoteque, nem degrade, nem mercantilize os valores ambientais e naturais, mas que os salvaguarde e garanta a sua sustentabilidade, enfrentando decididamente os constrangimentos externos que dificultam e impedem o desenvolvimento soberano de Portugal.

Nestas passagens, a argumentação é apoiada pelo uso do presente do conjuntivo que remete para um mundo potencial, diferente do mundo atual que o candidato critica, configurando, numa mesma unidade, um complexo ilocutório de crítica sobre o passado /presente e de proposta para o futuro. As duas realidades Passado + Presente vs Futuro são alvo de posicionamentos axiológicos antagónicos, sendo a primeira perspetivada como altamente negativa e a segunda, apresentada como altamente positiva, numa configuração polarizada do real.

Quanto às sequências encaixadas, podemos salientar que neste manifesto há dois grandes momentos expositivos, o primeiro, associado à descrição do papel do Presidente da República e a estruturas introduzidas por "O Presidente da República x"; o segundo, associado ao elenco das linhas de atuação fundamentais, previstas no programa do candidato: 
Linha D'Água (Online), São Paulo, v. 30, n. 1, p. 35-68, jun. 2017

(22) O Presidente da República tem um papel determinante na percepção pública de aspectos essenciais da evolução da situação nacional. O seu enquadramento no contexto do regime democrático constitucional, a responsabilidade acrescida que resulta da sua eleição directa apontam para uma intervenção política e institucionalmente activa. $\mathrm{O}$ respeito pelos outros órgãos de soberania e a salvaguarda da interdependência de poderes que a Constituição define obrigam a que o Presidente da República, quer recorrendo aos poderes de decisão que lhe são constitucionalmente conferidos, quer sabendo usar os seus poderes de influência, tenha tarefas inalienáveis e esteja incumbido de deveres indeclináveis.

A sequência instrucional / diretiva surge associada a atos ilocutórios diretivos, de recomendação e conselho que expressam necessidades de ação e deveres do candidato e de todos os portugueses. Nestes momentos, o Eu solicita que o Tu o acompanhe na necessária transformação social. São sequências introduzidas por fórmulas como "Urge x", "É preciso x", "Não podemos x":

(23) Urge encetar caminhos novos.

(24) É preciso defender a Autonomia.

(25) Não podemos tolerar que se dissimulem os níveis dramáticos de desemprego, das gritantes desigualdades sociais.

(26) Não nos podemos resignar à atual subordinação de Portugal aos centros do capitalismo (...).

\subsection{A componente semântica}

A componente composicional deu-nos já ensejo para apresentar as principais linhas orientadoras da organização semântica deste discurso onde se destacam os seguintes conteúdos: a apresentação do estado do país e aquilo que é urgente mudar; o programa que o candidato se propõe cumprir, caso seja eleito, e a descrição das funções do Presidente da República, segundo a sua visão. 
Linha D'Água (Online), São Paulo, v. 30, n. 1, p. 35-68, jun. 2017

Os seguintes excertos do manifesto materializam estas linhas temáticas essenciais: primeiramente, a descrição da situação do País, e também do Mundo, tal como mostra o exemplo seguinte:

(27) Este é um tempo em que, no Mundo, cresce uma perversa desigualdade económica entre os indivíduos e entre os países.

As principais questões abordadas são problemas sociais: desemprego, degradação social, falta de apoios, pobreza, grandes assimetrias sociais: enquanto alguns acumulam riquezas, outros vivem de forma miserável; crítica ao sistema capitalista, à sucessão de governos que não atuaram; crítica à perda de soberania de Portugal, de que é paradigmático o seguinte enunciado:

(28) Não podemos aceitar que Portugal deixe de ser senhor da sua própria História.

O candidato enumera todos os aspetos contra os quais todos devem lutar e introduz, posteriormente, a figura do Presidente da República enquanto Chefe de Estado e os seus papéis e deveres, fazendo ainda a caracterização da sua candidatura e dos valores que a pautam. Exemplos disso são:

(29) O Presidente da República, símbolo da unidade do Estado e da independência nacional, tem a particular responsabilidade na defesa de uma estratégia capaz de nos garantir a independência num mundo de grandes interdependências, em que os grandes poderes e os grandes interesses tendem a impor hegemonias limitativas da soberania dos Estados e da liberdade dos Povos.

(30) Esta candidatura que assumo exprime essa exigência de uma profunda ruptura e de viragem em relação às orientações políticas que tanta desordem e tanta regressão impuseram ao nosso País.

(31) Esta candidatura está comprometida com os valores de Abril, para impulsionar o caminho do desenvolvimento, da Justiça e do progresso social, da soberania e independência nacionais. 
$\mathrm{O}$ autor apresenta as linhas de atuação fundamentais do seu programa, que podemos sintetizar como: fazer cumprir a Constituição da República Portuguesa, defender a democracia, defender direitos, liberdades e garantias conquistados com a Revolução de Abril, fomentar o crescimento económico, pugnar pela igualdade e combater a pobreza, defender a independência e a unidade do Estado, sendo que para tal, como diz,

(32) É tempo de virar a página.

\subsection{A componente enunciativa: o Eu, o Outro e a polarização discursiva}

Do ponto de vista enunciativo, sabemos que este manifesto é da autoria de Edgar Silva, um dos dez candidatos à Presidência da República Portuguesa das eleições de 2016.

Este candidato, natural do Funchal, nasceu a 25 de Setembro de 1962, tendo-se licenciado em Teologia pela Universidade Católica Portuguesa e exercido funções de Padre Católico até 1997. Encetou, desde então, uma carreira política ativa, tendo sido, desde 1998, militante do PCP. Ocupava à data da candidatura, o cargo de deputado na Assembleia Legislativa da Região Autónoma da Madeira que tinha assumido desde 1996. Edgar Silva, que se considerava "um homem justo para Presidente”, disputou as eleições presidenciais portuguesas de Janeiro de 2016 com outros dez candidatos. Estas eleições consagrariam Marcelo Rebelo de Sousa como vencedor, ficando Edgar Silva em 50 lugar, com 3,95\% dos votos.

No momento da apresentação pública do manifesto em estudo, estamos, pois, num contexto pré-eleitoral para as presidenciais portuguesas de 2016, momento político marcado, simultaneamente, por uma forte crise económica e um quadro de indefinição política na assembleia legislativa continental.

Para além dos dados biográficos do Locutor como "ser do mundo" que trouxemos acima, é relevante, também, considerar como se processa a construção da imagem do Locutor como "ser do discurso" ${ }^{6}$, ou seja, como se processa a constru-

- Apesar de convocarmos aqui a dicotomia sugerida por Ducrot (1988) entre as figuras do "Locutor como ser do mundo" e o "Locutor como ser do discurso", não adotamos neste trabalho 
ção do seu ethos, pois sabemos que mais do que o locutor como ser do mundo, o que fica disponível para os leitores de um texto é essa imagem intradiscursiva que o locutor constrói de si mesmo através do texto e dos enunciadores que coloca em cena ${ }^{7}$. No caso deste manifesto, à semelhança do que acontece em muitos outros, a figura do Outro é também relevante na construção da representação discursiva do Eu, na medida em que a polarização entre estes dois actantes é uma estratégia retórica fortemente explorada para construir, nas palavras de Wodak (2001, p. 73) uma "positive self presentation" e uma "negative other presentation".

O Locutor apresenta a motivação da sua candidatura, ao mesmo tempo que inicia a construção da sua autoimagem, um ethos lutador, militante, responsável, cúmplice, que percebeu que unindo-se aos demais terá maior sucesso na sua empreitada. Apresenta-se como um resistente, que numa "imparável corrente", à qual se juntam homens e mulheres, busca a "libertação" de um estado de coisas que já dura há tempo demais. O Eu, enquanto indivíduo, só é explicitamente percetível na superfície do texto no início do mesmo, quando o candidato refere a sua candidatura como "minha própria intervenção" e, depois, já quase no final, quando identifica a luta pela qual assume ("assumo") a candidatura. Constrói, assim, uma autoimagem humilde, porque não salienta a sua individualidade face ao Tu nem assume o papel de protagonista na mudança do paradigma social. Através de um Nós inclusivo, o Eu identifica-se com o Tu, para reiterar que estão do "mesmo lado" e que pretendem o mesmo. O Nós inclusivo surge como forma de construção de um ethos em que as fronteiras entre o Eu e o Tu se esbatem: um ethos de pertença a uma coletividade.

A identificação entre o Eu e o Tu torna-se explícita nas formas verbais de 1. ${ }^{\mathrm{a}}$ pessoa do plural; nos pronomes e determinantes possessivos e em expressões contendo quantificadores universais como "todos":

a proposta do autor sobre o desdobramento enunciativo em cascata entre estas figuras e os enunciadores. Não o fazemos não por discordarmos da sua visão, mas porque a mesma não se ajusta aos nossos propósitos analíticos neste trabalho.

7 Aderimos aqui à concepção de Maingueneau (2005; 2008) - retomada já de Aristóteles - de que o ethos é uma construção discursiva. 
Linha D'Água (Online), São Paulo, v. 30, n. 1, p. 35-68, jun. 2017

(33) Esta candidatura é indissociável de um coletivo que a impulsiona e inseparável de uma memória viva (...).

(34) Assim, esta é a nossa candidatura, a nossa, de uma extensa e funda energia transformadora. Esta é, e será, a nossa candidatura a Presidente da República, a nossa, de um amplo movimento vital (...).

(35) Um outro Portugal é possível e está nas nossas mãos alcançá-lo.

(36) Não nos podemos resignar à atual subordinação de Portugal (...).

Já Benveniste (1966 (1986)) afirmava que o nós é uma junção entre o eu e o não-eu. Este não-eu pode ser o tu ou o eles, distinguindo-se a forma inclusiva (eu $+\mathrm{tu}$ ), que inclui o interlocutor, da forma exclusiva (eu + eles), de que o interlocutor é excluído. A maior parte das ocorrências do Nós no manifesto de Edgar Silva são ocorrências do Nós inclusivo, em que se fundem o eu e o $t u$.

O discurso também deixa transparecer um Eles, os responsáveis pelo estado de coisas negativo, os governos e a presidência anteriores, principalmente. Assim, o Eu faz uma distinção clara entre o Eu e o Tu como agentes positivos e o Eles / os Outros como agentes negativos, explorando esta dicotomia através do uso da dêixis pessoal, espacial e temporal. "Esta candidatura" que ele oferece como alternativa à degradação da situação do país é repetida várias vezes; "este é um tempo em que (...) cresce uma perversa desigualdade / se aprofundam injustiças " é outra das expressões várias vezes repetida para assinalar o tempo em que é urgente agir: o Agora. Se por um lado, através destes elementos deíticos temporais, o Eu demarca o momento presente, que é urgente mudar, através da dêixis pessoal, o Eu une-se ao Tu e separa-se dos Outros, dos responsáveis pela situação do país. Os Outros, que são diferentes do Tu a quem o Eu se dirige, são, ainda que não concretamente identificados, associados a um passado negativo que se estendeu até ao presente e que o Eu espera mudar no futuro. Eles / os Outros são associados àquilo que o Nós não pode tolerar: a estagnação, as desigualdades, a falta de perspetivas.

De forma a reforçar a sua estratégia argumentativa, o enunciador traz para o seu discurso vozes de autoridade que convoca para se autolegitimar. Algumas 
Linha D'Água (Online), São Paulo, v. 30, n. 1, p. 35-68, jun. 2017

dessas vozes, que configuram momentos de polifonia ${ }^{8}$ no texto, são a voz da Constituição Portuguesa, «A República Portuguesa é definida no artigo 2. ${ }^{\circ}$ da Constituição como "um Estado de direito democrático, baseado na soberania popular (...) e o aprofundamento da democracia participativa"», de que o Eu se socorre para justificar o seu combate contra o estado de coisas atual; a voz da Encíclica Papal Laudato $S i^{9}$, que é textualmente recuperada quando fala dos problemas do ambiente, "acentuam-se as chagas ambientais", entre outros momentos; e a voz do Programa do Partido Comunista Português, que enquadra ideologicamente o projeto de Edgar Silva, "Este é um tempo em que, em Portugal, depois de décadas de governação em confronto com os valores de Abril (...)", "A Lei constitucional ratifica e acolhe o inapagável acervo de conquistas e valores desse momento maior da história de Portugal que foi a Revolução de Abril”.

Uma isotopia muito forte de raiz judaico-cristã, "determinismos, fatalidades, resignação, consciência, chagas, clamor, libertação, flagelos”, reforça o diálogo interdiscursivo entre este manifesto e o sermão religioso, em que o candidato, à semelhança de um pregador, chama, de forma inflamada, a atenção para os problemas sociais que urge mudar.

O tom do discurso de Edgar Silva é, assim, um tom asseverativo. A presença da modalidade epistémica de certeza, na maior parte do seu discurso, marca a responsabilização total do locutor face àquilo que diz.

\subsection{A componente estilístico-fraseológica ou componente microestrutural}

No que diz respeito à componente microestrutural do manifesto, salienta-se a contribuição do léxico e das estruturas sintáticas para a polarização entre o Eu / Nós e

8 Reportamo-nos nesta abordagem sobre os momentos de polifonia, intertextualidade e dialogismo no manifesto tanto às concepções mais gerais de Bakthin (1977) como às concepções mais restritas de Ducrot (1988) sobre os conceitos em causa.

9 Agradecemos ao grupo de estudantes do Mestrado de Tradução e Serviços Linguísticos da Faculdade de Letras da Universidade do Porto, Maria João Correia, Miguel Esteves e Isabel de Sousa, o levantamento que fizeram sobre as manifestações de intertextualidade com a Encíclica Papal no manifesto de Edgar Silva. Não nos é possível mostrar neste trabalho o levantamento exaustivo dessas manifestações, sendo apenas possível exemplificar algumas delas. 
o Outro. A construção frásica, muito marcada pelo paralelismo estrutural; o uso de um léxico semanticamente forte e polarizado, com vista a extremar o Eu e o Eles / os Outros, configurando mesmo a formação de isotopias disfóricas; a modalização, assertiva de certeza, deôntica e avaliativa, que contribui para um discurso de condenação e recomendação moralista; e o uso de atos ilocutórios expressivos de crítica, diretivos de recomendação e compromissivos de promessa são os principais vetores a assinalar neste discurso.

Com efeito, o enunciador descreve uma imagem de um país carregada de negativismo, com uma isotopia repleta de léxico negativo ("fatalidade", "desassossego", "chagas", "flagelos"), mas deixa claro que a sua intenção é combater este estado de coisas, através do coletivo que impulsiona a sua candidatura, formado por pessoas que resistem e trabalham em prol de um objetivo comum. A utilização de léxico fortemente marcado de negatividade é um recurso, utilizado pelo enunciador ao longo do texto, para contrapor o Eu, que procura alcançar o Bem, a mudança, ao Eles, que simbolizam o Mal, a degradação e todos os flagelos que atingem o país. A construção desta polarização é conseguida através não só de adjetivos, como também de verbos e substantivos.

(37) Este é um tempo em que, no Mundo, cresce uma perversa desigualdade económica entre os indivíduos e entre os países.

(38) Multiplica-se a degradação social.

(39) Acentuam-se as chagas ambientais e agravam-se os problemas dos trabalhadores e alastra a pobreza, tudo na decorrência direta do dominio absoluto dos grandes grupos económicos.

(40) (...) multiplicando focos de tensão e de guerra (...).

(41) (...) espalhando os terriveis flagelos das migrações forçadas e dos refugiados, do desemprego, da fome e da miséria, que mergulham grande parte da Humanidade em indizíveis carências e intoleráveis sofrimentos.

(42) Deste modo, degrada-se a injusta ordem internacional assente na despótica lógica dos mercados que, por cima dos Povos e dos Estados, se vai apropriando de todas as decisões e escolhas (...). 
Linha D'Água (Online), São Paulo, v. 30, n. 1, p. 35-68, jun. 2017

$\mathrm{O}$ Eu contrapõe aqueles que sofrem injustiças àqueles cujo poder é quase ilimitado, numa divisão entre um Eu, que é também Nós, e um "Eles", aqueles que conduziram a este estado de coisas. Este grupo, responsável por tudo o que é urgente mudar, não é identificado, pois o autor recorre a construções impessoais (“degrada-se", "se vai apropriando").

Como referimos já, é notória, ao longo do discurso, a oposição entre o tempo presente ("este é o tempo"), que é o tempo de mudança, e o tempo que tem sido vivido até ao momento, "contrário aos valores de Abril", com o aprofundar de desigualdades e exploração. $\mathrm{O}$ Eu afirma já conhecer e partilhar com o Tu a consciência de que o caminho que se tem percorrido deve ser mudado urgentemente. Quando o Eu afirma que não é aceitável manter-se tal estado de coisas, dá-se o ponto de viragem.

(43) Este é um rumo inaceitável.

(44) Este é um caminho inaceitável.

(45) Este é um caminho inaceitável. Este não é o Portugal que a Constituição configura.

A ideia de que é chegado o momento ideal para a mudança consolida-se ainda com a utilização do Nós inclusivo, do qual o Eu se serve para marcar o ponto de viragem: o Nós, constituído pelo Eu e pelo Tu, não pode deixar de se revoltar contra tal estado de coisas. Assim, o Eu serve-se novamente do paralelismo estrutural, já patente no uso de "Este é um rumo / caminho inaceitável”, reiterando que Eu e Tu devem estar unidos no combate à situação política e social atual.

(46) Não podemos aceitar que Portugal deixe de ser senhor da sua própria História.

(47) Não podemos capitular perante o intolerável ataque às funções sociais do Estado (...)

(48) Não podemos aceitar a ofensiva contra o trabalho com direitos.

(49) Não podemos pactuar com o corte nas prestações sociais, com o roubo aos rendimentos, com a brutal injustiça fiscal (...). 
O uso continuado do paralelismo estrutural contribui para a expressão da união do Eu e do Tu, em que o enunciador tenta trazer o Tu para o seu universo, para juntos lutarem contra todo o espaço ideológico que foi criado desde o início do discurso. Reitera-se a ideia de que é "inaceitável” o caminho que tem vindo a fazer-se, e de que existe uma alternativa; que o Tu não está condenado a continuar neste cenário sem esperança; pode, sim, alcançar uma outra realidade. Para tal, o Eu fornece o caminho para a alcançar: a sua candidatura, que é, como já haviamos dito, não só dele, como de todos os portugueses.

Existe, pois, uma polarização muito forte entre o "Bem" e o "Mal", estando o Eu e o Tu do lado do Bem, por essa razão, devendo unir-se pelo voto; e todos aqueles que, segundo o Eu, levaram à conjuntura atual, situando-se do lado do Mal.

As modalidades assertiva de certeza, deôntica e avaliativa são as predominantes no texto. A autolegitimação do Eu é construída com recurso a estas modalidades, que marcam um total envolvimento enunciativo de um ethos militante. A modalidade deôntica, expressa pela proliferação de construções como "não podemos", "é preciso" ou "urge", surge associada ao que deve e ao que é preciso ser feito; as assertiva e avaliativa, expressas pelo presente do indicativo, pelo futuro e pelo léxico forte, surgem associadas à caracterização do estado de coisas que tem de ser alterado e aos compromissos de mudança executados pelo locutor.

No discurso o presente do indicativo predomina, e por isso mantém-se a ideia de atualidade, quer do universo ideológico negativo, quer da necessidade de lutar contra ele. O presente do indicativo empregue significa, por vezes, um presente que se tem estendido ao longo do tempo e que refere estados de coisas continuados:

(50) (...) multiplica-se a degradação (...) acentuam-se as chagas (...) alastra a pobreza, tudo na decorrência direta do domínio absoluto dos grupos económicos.

Outras vezes é um presente que se projeta no futuro, diretamente ligado ao caráter deôntico das expressões em que ocorre ("não podemos", "é preciso", "urge").

A organização do discurso da forma descrita acima possibilita que o Eu se apresente como a solução para os graves problemas que critica, surgindo a sua candidatura envolvida numa aura de messianismo que lhe confere uma força acrescida. 
Linha D'Água (Online), São Paulo, v. 30, n. 1, p. 35-68, jun. 2017

\section{Conclusão}

Procuramos neste trabalho expor os principais eixos organizadores do manifesto presidencial do candidato Edgar Silva à Presidência da República Portuguesa nas eleições de janeiro de 2016.

Verificamos, com a ajuda da proposta de J. M. Adam (2001) para a análise de gêneros em oito componentes, que o texto de Edgar Silva se integra na caracterização prototípica do gênero manifesto político (PINTO, 2013; PINTO, 2015). A sua construção assenta na divisão em duas grandes partes: uma parte destinada a diagnosticar o estado do país, marcada pelo predomínio de sequências argumentativas com a presença das modalidades deôntica, avaliativa e de atos ilocutórios expressivos de crítica; outra parte, destinada a apresentar o programa de ação do candidato, onde se mesclam as sequências argumentativas com as expositivas, a modalidade assertiva de certeza e onde surgem os atos compromissivos de promessa e os atos diretivos de apelo.

A força discursiva, num texto com alto teor retórico, constrói-se também por recurso a um léxico muito marcado por valores semânticos disfóricos e a estruturas sintáticas paralelísticas. A polarização entre eixos tais como o Eu/Nós e o Eles/os Outros; o Bem e o Mal; o Passado e o Futuro é também um eixo de organização relevante neste discurso, que investe fortemente na construção de um ethos militante, solidário e simbiótico com o coletivo que o apoia.

Trata-se, enfim, de um discurso forte, comprometido, que revela uma total responsabilização por parte do locutor face àquilo que diz e que cumpre prototipicamente os objetivos pragmáticos do gênero em que se integra.

\section{Anexo}

\section{DECLARAÇÃO DE CANDIDATURA}

15 OUTUBRO 2015, LISBOA 
Linha D'Água (Online), São Paulo, v. 30, n. 1, p. 35-68, jun. 2017

Esta candidatura é indissociável de um colectivo que a impulsiona e inseparável de uma memória viva, de uma longa história de resistência e de projecto. Há uma memória partilhada e vivida por tantos homens e tantas mulheres que não se resignam, nem se renderam ao mal da resignação. Há uma longa marcha do sentido do intolerável. Contrariando pretensos determinismos e diversas fatalidades, existe uma imparável corrente de homens e de mulheres com a consciência de que a História não pode ser parada. Muitas e inúmeras mãos querem a transformação da História. Esse desassossego corresponde a um longo caminho de procura de afirmação do humano, à construção de percursos concretos de libertação. É porque reconheci, com a minha própria intervenção, que as causas e lutas de cada um, por mais generosas e empenhadas que sejam, ganham mais força e sentido material quando partilhadas colectivamente, que aqui cheguei a este espaço de luta comum.

Assim, esta é a nossa candidatura, a nossa, de uma extensa e funda energia transformadora. Esta é, e será, a nossa candidatura a Presidente da República, a nossa, de um amplo movimento vital para a libertação de todos e de cada um dos homens e de cada uma das mulheres.

Este é um tempo em que, no Mundo, cresce uma perversa desigualdade económica entre os indivíduos e entre os países. Multiplica-se a degradação social. Acentuam-se as chagas ambientais e agravam-se os problemas dos trabalhadores e alastra a pobreza, tudo na decorrência directa do domínio absoluto dos grandes grupos económicos. Deste modo, degrada-se a injusta ordem internacional assente na despótica lógica dos mercados que, por cima dos Povos e dos Estados, se vai apropriando de todas as decisões e escolhas, multiplicando focos de tensão e de guerra, espalhando os terríveis flagelos das migrações forçadas e dos refugiados, do desemprego, da fome e da miséria, que mergulham grande parte da Humanidade em indizíveis carências e intoleráveis sofrimentos.

Este é um tempo em que, em Portugal, depois de décadas de governação em confronto com os valores de Abril, se aprofundam as injustiças sociais e a exploração, e medram a corrupção e a concentração da riqueza. Conhecemos esta trajectória de descaracterização do regime democrático, de ataque à soberania e independência nacionais.

Este é um rumo inaceitável. 
Linha D'Água (Online), São Paulo, v. 30, n. 1, p. 35-68, jun. 2017

Não podemos ficar indiferentes ao acentuar do processo de regressão social, de acumulação e polarização da riqueza. Não podemos aceitar a continuada alienação do património público e a destruição da nossa estrutura produtiva. Não podemos tolerar que se dissimulem os níveis dramáticos de desemprego, das gritantes desigualdades sociais, de negação a milhões de Portugueses, em particular às camadas jovens, da perspectiva de terem direito a condições de vida dignas e de realizarem os seus projectos pessoais e profissionais no País que é seu.

Não nos podemos resignar à actual subordinação de Portugal aos centros do capitalismo, expressa pela União Europeia através de pactos e programas que só agridem as condições de vida dos Portugueses e comprometem o futuro do País.

Este é um caminho inaceitável.

Não podemos aceitar que Portugal deixe de ser senhor da sua própria História. A História mostra-nos períodos vários de efectiva subordinação a terceiros das nossas condições de decisão política. Nos nossos dias, o País está a ser saqueado e destruído pelos especuladores, e os responsáveis pela governação decretaram a subordinação de Portugal aos mercados, a subserviência ao grande capital estrangeiro, a submissão à Troika, a subjugação aos especuladores e agiotas.

Este é um caminho inaceitável.

O Presidente da República, símbolo da unidade do Estado e da independência nacional, tem a particular responsabilidade na defesa de uma estratégia capaz de nos garantir a independência num mundo de grandes interdependências, em que os grandes poderes e os grandes interesses tendem a impor hegemonias limitativas da soberania dos Estados e da liberdade dos Povos.

Não podemos capitular perante o intolerável ataque às funções sociais do Estado, face ao corte no investimento público e à desagregação da Administração Pública. Não podemos ser cúmplices do ataque ao Serviço Nacional de Saúde e à Escola Pública. Não podemos aceitar a ofensiva contra o trabalho com direitos. Não podemos pactuar com o corte nas prestações sociais, com o roubo aos rendimentos, com a brutal injustiça fiscal, com o desemprego, a precariedade, a violação de direitos, enquanto se refina a protecção e apoio ao grande capital, que não pára de aumentar os seus colossais lucros. 
Linha D'Água (Online), São Paulo, v. 30, n. 1, p. 35-68, jun. 2017

Este é um caminho inaceitável. Este não é o Portugal que a Constituição configura. Um outro Portugal é possível e está nas nossas mãos alcançá-lo. E é em nome da luta por esse futuro que assumo esta candidatura.

\section{II - QUEM ACOLHE O GRITO DOS POBRES?}

Quem, nesta República, tem em conta os direitos fundamentais dos mais desfavorecidos? Quem escuta o clamor dos excluídos deste mundo? Quem responde por milhões de pessoas indefesas face aos "interesses do mercado divinizado, transformado em regra absoluta"? Quem responde por tanta gente sacrificada pela desenfreada especulação financeira? Quem acolhe o grito das vítimas dos poderes económicos e dos seus interesses predominantes que arrasam tanta vida e a fonte da vida? Quem se compromete com a justa causa daqueles que estão a ser sufocados pelo domínio absoluto do lucro?

Existem práticas de exploração, de injustiças e de rapina, benefícios que só a alguns poucos aproveitam, formas de dominação em função do lucro, que são a raiz profunda da desordem.

Urge encetar caminhos novos. O sistema de injustiça precisa de ser substituído, com uma viragem à altura das circunstâncias. $\mathrm{O}$ domínio despótico do poder financeiro, e a sua perversa ordem, requer a tomada de decisões para inverter a desordem estabelecida.

A injustiça não é invencível!

$\mathrm{Na}$ Constituição do nosso País, o Presidente da República não governa. Mas o Presidente da República não poderá ser indiferente às carências que os Portugueses sofrem, não poderá ser insensível à exploração que a pobreza comporta, não pode fechar os olhos aos dramas de milhões de pobres, ao desânimo e à desesperança de cada rosto, e de tantos rostos relegados para o silêncio das margens, expulsos, neste País, para as ultraperiferias sociais.

Como Presidente da República, estarei sempre ao lado dos que defendem a Justiça Social. Como Presidente da República, lutarei contra a injustiça. Tanto no exercício de poderes de decisão, como no uso do diálogo e da palavra, assumo e assumirei o compromisso da opção preferencial pelos mais pobres, pelos explorados. 
Linha D'Água (Online), São Paulo, v. 30, n. 1, p. 35-68, jun. 2017

Não é um compromisso de agora. É um compromisso que tem orientado toda a minha vida.

\section{III - QUEM ATENDE AO CLAMOR DOS TRABALHADORES?}

Quem, em nome da República, dá expressão aos interesses dos trabalhadores e aos seus direitos no emprego? Quem responde por milhares de desempregados e pelas condições de vida e de trabalho?

Quando o grande patronato aumenta o seu poder sobre os trabalhadores, generalizam-se as formas de precariedade no trabalho, é brutal a violência do ataque aos direitos laborais, aumenta a exploração e a liquidação de direitos e conquistas - como se verifica em relação ao direito à contratação colectiva. Desvalorizam-se os salários e cresce a insegurança na vida de quem vive do trabalho e do seu salário. Desregulam-se horários, rouba-se o direito ao lazer e à família, precariza-se a organização da vida de centenas de milhares de trabalhadores. Nestes nossos dias, há uma outra realidade inquietante, boa parte dos trabalhadores vivem na pobreza. Para milhares de trabalhadores não basta que tenham emprego para que se libertem da pobreza.

Como candidato a Presidente da República e como Presidente da República, defenderei um outro rumo para Portugal que comporte a valorização do trabalho e dos trabalhadores, de afirmação dos seus direitos, que combata a precariedade e o desemprego, um rumo que tenha no aumento dos salários, na elevação do poder de compra, um factor decisivo de justiça social e de contribuição incontornável para reduzir as desigualdades na distribuição do rendimento.

\section{IV - QUEM, NESTA REPÚBLICA, OUVE O CLAMOR DA TERRA?}

Quem acolhe o grito da Natureza? Quem responde pelos danos humanos e ambientais, como o das aldeias sem vida, da desflorestação, dos fogos florestais, dos mares e dos rios poluídos, da destruição das fontes de água doce e dos obstáculos ao fundamental acesso à água potável e pública? Quem escuta as vítimas do actual modelo de desenvolvimento, produção e consumo? Quem assume responsabilidades pelas nocivas alterações dos ecossistemas e pela perda da biodiversidade? 
Linha D'Água (Online), São Paulo, v. 30, n. 1, p. 35-68, jun. 2017

Há o mito do progresso, a sacralização dos mercados, apostando num ganho imediato, uma lógica férrea, uma lógica de dominação, que se invoca omnipotente, de certos interesses económicos sobre a Natureza, deixando um rasto de danos humanos e ambientais.

Para uma responsável utilização dos recursos nacionais, o Estado não se pode demitir das obrigações de planificar, coordenar, vigiar e sancionar, tal como prevê o texto constitucional.

Na Constituição da República, o Presidente da República não governa, mas não renuncia à sua cidadania e, muito menos, aos deveres de defesa do interesse nacional. Está, por isso, obrigado, também nesta área, ao dever de incentivar boas práticas, promover a busca de novos caminhos, estimular iniciativas, projectos e políticas alternativas.

\section{V - O PAPEL DO PRESIDENTE DA REPÚBLICA}

O Presidente da República tem um papel determinante na percepção pública de aspectos essenciais da evolução da situação nacional. $\mathrm{O}$ seu enquadramento no contexto do regime democrático constitucional, a responsabilidade acrescida que resulta da sua eleição directa apontam para uma intervenção política e institucionalmente activa. O respeito pelos outros órgãos de soberania e a salvaguarda da interdependência de poderes que a Constituição define, obrigam a que o Presidente da República, quer recorrendo aos poderes de decisão que lhe são constitucionalmente conferidos, quer sabendo usar os seus poderes de influência, tenha tarefas inalienáveis e esteja incumbido de deveres indeclináveis.

O Presidente da República não pode deixar, no âmbito das suas competências e responsabilidades próprias, de defender a mobilização do Povo Português na busca de um outro rumo de desenvolvimento.

E é neste sentido que consideramos que os poderes do Presidente da República podem e devem ser usados ao serviço da ruptura com o rumo das últimas décadas.

Se é verdade que o Presidente da República não é governo deve, no entanto, actuar no quadro das funções que a Constituição lhe confere, usando os seus poderes para determinar a mudança, para influenciar um rumo de desenvolvimento, justiça e progresso social para Portugal. 
Linha D'Água (Online), São Paulo, v. 30, n. 1, p. 35-68, jun. 2017

Esta candidatura que assumo exprime essa exigência de uma profunda ruptura e de viragem em relação às orientações políticas que tanta desordem e tanta regressão impuseram ao nosso País.

Esta é uma candidatura que afirma que há um outro rumo e uma outra política capazes de responder aos problemas de Portugal.

Esta candidatura está comprometida com os valores de Abril, para impulsionar o caminho do desenvolvimento, da Justiça e do progresso social, da soberania e independência nacionais.

Esta candidatura está vinculada, inabalavelmente, ao projecto de Abril, inscrito na Constituição da República Portuguesa, que comemora, em breve, o seu 40. ${ }^{\circ}$ aniversário, que incorpora uma base programática e constitui uma plataforma política capaz de unir os Portugueses no abrir das novas avenidas de esperança e de futuro para Portugal.

\section{VI - LINHAS DE ACTUAÇÃO FUNDAMENTAIS}

1. Defender, cumprir e fazer cumprir a Constituição da República Portuguesa.

Questão central dos tempos que vivemos é o empenhamento na defesa da Constituição da República. Defesa contra a sua constante violação e o desrespeito pelo que ela contém de positivo, e muito é, mas igualmente contra a permanente ameaça e os projectos latentes para a sua liquidação definitiva.

É na Lei fundamental, e no respeito e efectivação dos seus princípios e normas, que se podem e devem encontrar as saídas para a dramática situação com que o País está confrontado.

A Lei constitucional ratifica e acolhe o inapagável acervo de conquistas e valores desse momento maior da história de Portugal que foi a Revolução de Abril. Podia não ter sido assim. Mas foi de facto assim, e esse facto deve ser reconhecido se queremos honrar a memória histórica, ou seja, a memória viva do Povo português.

Por isso, a exigência do cumprimento e respeito pela Constituição tornou-se um factor crucial na defesa do regime democrático, um referencial para qualquer política que se assuma como patriótica e de esquerda. E também por isso, numa situação política particularmente grave e muito perigosa, a unidade e convergência dos trabalhadores, dos patriotas, dos homens e mulheres democratas em torno da 
Linha D'Água (Online), São Paulo, v. 30, n. 1, p. 35-68, jun. 2017

sua defesa deve constituir um imperativo, bem assim como a afirmação de uma política alternativa que respeite os valores de Abril.

2. Defender e aprofundar o regime democrático.

A República Portuguesa é definida no artigo 2..$^{\circ}$ da Constituição como "um Estado de direito democrático, baseado na soberania popular, no pluralismo de expressão e organização política democráticas, no respeito e na garantia de efectivação dos direitos e liberdades fundamentais e na separação e interdependência de poderes, visando a realização da democracia económica, social e cultural e o aprofundamento da democracia participativa”. Seguramente que ninguém encontrará muitas semelhanças entre esta definição e o panorama actual da sociedade portuguesa.

Existem em muitos aspectos da realidade presente desfiguramentos e retrocessos, e uma clara degradação do regime e da ética democráticas a que é necessário dar resposta.

A alternativa à democracia existente é mais e melhor Democracia.

A afirmação de um Portugal livre e democrático constitui um objectivo que exige a defesa do regime democrático, o respeito pela separação dos poderes, uma justiça independente, democrática, acessível e igual para todos, o combate decidido à corrupção e ao crime económico, o combate à promiscuidade entre o poder político e económico. A par de uma política de Defesa Nacional ao serviço da soberania e independência nacionais, que garanta o respeito pelo princípio constitucional de separação entre Forças Armadas e segurança interna e uma política de segurança pública que defenda os direitos dos cidadãos e a tranquilidade pública.

A minha candidatura defende o aprofundamento da Democracia como um factor imprescindível de desenvolvimento e transformação, vê na participação democrática dos cidadãos em todos os planos da vida colectiva, e na defesa dos direitos, liberdades e garantias, constitucionalmente consagrados, uma pedra angular do reforço, do enraizamento e do aprofundamento do regime democrático.

3. Defender os direitos, liberdades e garantias dos trabalhadores. 
Linha D'Água (Online), São Paulo, v. 30, n. 1, p. 35-68, jun. 2017

A degradação do regime democrático é inseparável de uma intensa e prolongada ofensiva contra os direitos económicos, sociais e culturais dos trabalhadores, e de uma persistente desvalorização do trabalho.

Se a Constituição da República Portuguesa reconhece um amplo leque de direitos, liberdades e garantias aos trabalhadores, no plano individual e no plano colectivo, fá-lo no quadro do reconhecimento de que esses direitos constituem não apenas um elemento estruturante do regime democrático, mas também que o seu exercício é parte integrante do seu desenvolvimento, e do desenvolvimento económico e social do País.

Comprometo-me, pois, a tudo fazer quanto à salvaguarda da "Constituição Laboral", naquele que é o capítulo sobre os direitos, liberdades e garantias dos trabalhadores.

\section{Defender os direitos sociais.}

Os direitos - que a Constituição consagra para todos - à saúde e à protecção social, à cultura, à educação e ao ensino, o acesso ao direito e aos tribunais, nomeadamente, são crescentemente negados.

O Estado tem hoje um papel muito limitado na promoção do acesso à habitação. As famílias são afectadas por múltiplas formas, do desemprego e da precariedade à carência de apoios sociais, à altíssima taxa de dependência dos jovens e às dificuldades que defrontam para conseguir uma vida independente. Sobre as mulheres, as primeiras a ser atingidas pelos despedimentos, recaem as consequências da ausência de apoios, nomeadamente à maternidade e à primeira infância. Está ausente uma política de apoio aos cidadãos portadores de deficiência. Mantém-se por realizar uma política de integração social, económica e cultural dos imigrantes. E a pretexto de que a base de defesa dos direitos sociais se encontra em crise, a política de direita descapitaliza a Segurança Social e favorece as seguradoras e os fundos de pensões privados, altera de forma injusta e desumana a idade da reforma, penaliza ainda mais os desempregados e os jovens à procura de primeiro emprego, mantém em condições de pobreza extrema a grande massa dos reformados, pensionistas e idosos. 
Linha D'Água (Online), São Paulo, v. 30, n. 1, p. 35-68, jun. 2017

Estas políticas violam tão frontalmente direitos sociais elementares, atingem tão duramente uma tão grande massa de Portugueses e Portuguesas, entre os mais desprotegidos e pobres, constituem uma tão implacável violência social, que nenhum responsável político, e muito menos um Presidente da República, lhes poderá ser indiferente.

5. Promover o crescimento económico e o desenvolvimento.

Ao arrepio das incumbências constitucionais (nomeadamente as contidas nos artigos $80 .^{\circ}$ e $81 .^{\circ}$ ), através das privatizações e dos compromissos assumidos no quadro da integração europeia, foram subtraídas ao Estado alavancas essenciais de intervenção e regulação, e de concretização de políticas capazes de promover um desenvolvimento equilibrado.

Defendo que um outro Portugal é possível. Com uma economia mista que defenda os recursos e a produção nacional, o emprego, que promova a ciência e a tecnologia, que desenvolva e modernize as capacidades produtivas nacionais, que desenvolva a economia do mar e apoie os pescadores, apoie e incentive as micro, pequenas e médias empresas. Com uma perspectiva de desenvolvimento que não abandone o interior, que apoie os pequenos e médios agricultores, nem promova uma desequilibrada concentração de populações, equipamentos, actividades e serviços em áreas desordenadas e entregues à especulação imobiliária. Com um modelo de desenvolvimento que não hipoteque, nem degrade, nem mercantilize os valores ambientais e naturais, mas que os salvaguarde e garanta a sua sustentabilidade, enfrentando decididamente os constrangimentos externos que dificultam e impedem o desenvolvimento soberano de Portugal.

6. Lutar contra a exclusão social e pela erradicação da pobreza.

Não olhamos a pobreza e os pobres em Portugal ao nível da crítica moral ou da superficial denúncia ética, mas ao nível da economia política. Os pobres e a pobreza são uma realidade estruturalmente enraizada na forma como se organiza determinado desenvolvimento. A pobreza não é apenas consequência das contradições de algumas más vontades individuais, mas das contradições estruturais da organização económica. 
Linha D'Água (Online), São Paulo, v. 30, n. 1, p. 35-68, jun. 2017

Portugal apresenta um dos maiores índices de pobreza da Europa. As políticas dos últimos anos agravaram ainda mais as desigualdades sociais e a pobreza. Um modelo económico assente em baixos salários e em baixos níveis de qualificação, a crescente desresponsabilização do Estado das suas funções sociais, o forte agravamento do desemprego, a contenção dos rendimentos, os cortes nas pensões e salários, somados à redução dos apoios sociais, provocaram danos profundos que comprometem o futuro do País e da nossa vida em comum.

Comprometo-me com a causa da libertação das amarras da pobreza, encarando-a como dever do Presidente da República, na imperiosa tarefa de intervenção na defesa dos direitos humanos, na promoção de uma sociedade democrática assente nos valores da dignidade humana, da Justiça Social e da responsabilidade colectiva.

7. Garantir toda a prioridade às crianças e combater o crime da pobreza infantil. Vivem-se hoje dias de retrocesso objectivo na garantia e cumprimento dos direitos das crianças.

As crianças são uma das principais vítimas da crise, ou seja, das políticas dos governos e da União Europeia para lançar dinheiro para os bancos e acumular lucros, atirando milhares de crianças a pobreza.

As causas são: a diminuição dos montantes e a abrangência das prestações sociais como o Abono de Família, a Acção Social Escolar, os Subsídios Sociais de Parentalidade, o Rendimento Social de Inserção e o Subsídio Social de Desemprego. Entre 2009 e 2012, o Governo Português retirou a 30\% das crianças um dos seus direitos intrínsecos - o direito ao Abono de Família. A falta de resposta séria de políticas dirigidas à atenuação do risco de pobreza e exclusão social expressa-se na clara fragilidade e vulnerabilidade das crianças portuguesas.

Os impactos desta situação no futuro das crianças, e no futuro do País, são imprevisíveis e podem ser mesmo, para muitas, irreversíveis.

Comprometo-me com esta justa causa, que não é de hoje, a qual, em última instância, visa uma outra cultura dos direitos.

8. Afirmar um Estado participado e descentralizado, no respeito pelo seu carácter unitário. 
Linha D'Água (Online), São Paulo, v. 30, n. 1, p. 35-68, jun. 2017

A afirmação das Autonomias Regionais, a defesa e valorização do Poder Local Democrático e a regionalização administrativa, constituem elementos insubstituíveis da organização democrática do Estado.

É preciso defender a Autonomia, reedificar o edifício autonómico, tornando -o leal às aspirações das populações e fazendo dele o reflexo dos ideais que, durante séculos, nortearam as lutas dos Povos insulares, lutas essas que tiveram expressão em 1976, na Constituição da República Portuguesa, com o reconhecimento do direito à autonomia político-administrativa dos Açores e da Madeira.

É preciso inverter o processo de ataque e desfiguração do Poder Local Democrático, e reconduzi-lo por via das condições que lhe são devidas de autonomia administrativa e financeira ao papel que são chamadas a preencher na promoção das condições de vida, na coesão territorial e na dinamização da actividade económica das comunidades locais.

Comprometo-me a defender uma política determinada pela valorização do Poder Local Democrático, pela criação das regiões administrativas, como determina a Constituição, e em favor das regiões insulares distantes pela vitalização da Autonomia e pelo aperfeiçoamento dos instrumentos adequados ao seu aprofundamento.

\section{Atender à diáspora portuguesa.}

As comunidades portuguesas constituem um vector estratégico para a afirmação e projecção de Portugal no mundo.

Nos últimos anos, as políticas praticadas pelos vários governos ficaram marcadas pela aplicação de medidas lesivas tanto dos interesses e direitos das comunidades portuguesas como dos interesses nacionais. Do encerramento de consulados à ausência de acções diplomáticas que respondam aos inúmeros casos de pobreza que atingem muitos compatriotas, foram políticas sem justificação à luz de nenhum critério que não seja o de discriminar, castigando quem já tem de ultrapassar tantas vicissitudes, e que ademais são potenciadoras do definhamento dos laços identitários da comunidade portuguesa com Portugal. 
Linha D'Água (Online), São Paulo, v. 30, n. 1, p. 35-68, jun. 2017

Comprometo-me, entre outros objectivos, a promover a participação cívica e política e o diálogo com as estruturas representativas da Diáspora e a respeitar a autonomia e a legitimidade institucional do Conselho das Comunidades Portuguesas.

\section{Defender a independência nacional.}

Intensificou-se o ataque à democracia e à soberania nacional. Os Portugueses têm sido expropriados do seu poder soberano de decisão sobre as questões essenciais da vida do País. São cada vez mais as decisões transferidas para estruturas supranacionais em colisão com a Constituição da República. Sucessivos governos, do PS, do PSD e do CDS, têm assumido como legítima a intervenção estrangeira sobre o País, esvaziando e amputando o regime democrático e a soberania nacional.

É tempo de virar a página.

A ruptura com a dependência e subordinação externas - nas suas variadas expressões, dimensões e domínios de política de Estado - constitui uma condição crucial para a afirmação da independência e soberania nacionais.

Aqui me comprometo com políticas que recusem a submissão do País a ditames e políticas atentatórios dos direitos e interesses do Povo português e da democracia, com políticas que confiem na força e capacidades do Povo para recuperar para Portugal os instrumentos de soberania necessários ao progresso e desenvolvimento do País.

Aqui me comprometo, tendo como referência o artigo $7^{\circ}$ da CRP, a intervir no âmbito dos poderes presidenciais, a que Portugal pratique uma politica diversificada de relações internacionais de paz, amizade e cooperação com todos os Povos.

Com esta candidatura assumo plenamente o exercício de todos os direitos, desde a apresentação até ao voto, e afirmo a total disponibilidade para exercer as funções que o Povo Português entenda atribuir-me nesta eleição.

Com toda a confiança esta minha, e nossa, candidatura irá avançar por todo o País. 
Linha D'Água (Online), São Paulo, v. 30, n. 1, p. 35-68, jun. 2017

Como candidato ou como Presidente da República defenderei, intransigentemente, os ideais libertadores de Abril, a nossa Constituição da República e o regime democrático que ela consagra e projecta.

Viva a Liberdade e a democracia!

Viva o 25 de Abril!

Viva Portugal!

http://edgarsilva2016.pt/declaracao

\section{Referências}

ADAM,J.-M. (2001). En finir avec les types de textes. In: BALLABRIGA, M. (Org.), Analyse des discours. Types et genres: Communication et interprétation. Toulouse: EUS. p. 25-43.

ADAM, J.-M. \& HEIDMANN, U. (2007). Six propositions pour l'étude de la généricité. La Licorne 79. Rennes: Presses Universitaires de Rennes, p. 21-34.

ADAM, J.-M. (2011). A linguística textual: introdução à análise textual dos discursos. 2 ed., São Paulo: Cortez.

BAKTHINE, M. (1977). Le Marxisme et la Philosophie du Langage - essai d'application de la méthode sociologique en Linguistique. Paris: Édtions de Minuit.

BENVENISTE, É. ((1966) 1986). "L'homme dans la langue” in Problèmes de linguistique générale I, Paris, Gallimard, O Homem na linguagem (tradução portuguesa Maria Alzira Seixo), Lisboa: Vega Editora.

CAMPOS, M. H. C. (1998). Dever e Poder - Um subsistema modal do português. Lisboa: Fundação Calouste Gulbenkian.

DUCROT, Oswald (1988). Polifonia Y Argumentación. Universidade del Valle, Colombia: Cali.

MAINGUENEAU, D. (2005). Ethos, cenografia, incorporação. In: AMOSSY, R. (Org.). Imagens de si no discurso: a construção do ethos. São Paulo: Contexto.

PINTO, A. A. G.; PINHO, A. C. F. A.; TEIXEIRA, J. F. P. Polarização e 
Linha D'Água (Online), São Paulo, v. 30, n. 1, p. 35-68, jun. 2017

MAINGUENEAU, D. (2008). A propósito do ethos. In: Motta, A. R.; Salgado, L. S.(Orgs.) Ethos discursivo. São Paulo: Contexto, p. 11-29.

PINTO, A. G. (2013). Dialogismo, polifonia e heterogeneidade enunciativa nos manifestos políticos das presidenciais de 2011. Estudos Linguísticos, Gramática e Texto. Universidade Nova de Lisboa: Edições Colibri, 8, p. 195-212.

PINTO, A. G. (2015). A Retórica do Eu e do Outro - The Othering. A gramática da identidade no discurso político. Estudos do discurso: caminhos e tendências. Paulistana Editora. Universidade Nova de Lisboa: Edições Colibri, 8, p. 195-212.

SEARLE, J. (1976). A classification of illocutionary acts. Cambridge: Cambridge University Press. WODAK, R. (2001) The discourse historical approach. In: WODAK, R. \& MEYER, M. (eds) Methods of Critical Discourse Analysis. London: Sage, p. 63-94.

Recebido: 29/05/2017. Aprovado: 12/08/2017. 